\title{
Determination of acrolein, ethanol, volatile acidity, and copper in different samples of sugarcane spirits
}

\author{
Determinação de acroleína, etanol, acidez volátil e cobre em diferentes amostras de aguardentes de cana
} José MASSON ${ }^{1,2}$, Maria das Graças CARDOSO ${ }^{3 \star}$, Lidiany Mendonça ZACARONI ${ }^{3}$, Jeancarlo Pereira dos ANJOS, Adelir Aparecida SACKZ ${ }^{3}$, Ana Maria de Resende MACHADO ${ }^{1,4}$, David Lee NELSON ${ }^{5}$

\begin{abstract}
Seventy-one samples of sugarcane spirits from small and average size stills produced in the northern and southern Minas Gerais (Brazil) were analyzed for acrolein using HPLC (High Performance Liquid Chromatography). Ethanol and copper concentrations and volatile acidity were also determined according to methods established by the Ministry of Agriculture, Livestock and Supply (MAPA). A total of 9.85\% of the samples tested showed levels of acrolein above the legal limits, while the copper concentrations of $21.00 \%$ of the samples and the volatile acidity of $8.85 \%$ of the samples were higher than the limits established by the Brazilian legislation. The concentration of acrolein varied from 0 to $21.97 \mathrm{mg} .100 \mathrm{~mL}^{-1}$ of ethanol. However, no significant difference at $5 \%$ of significance was observed between the samples produced in the northern and southern Minas Gerais. The method used for determination of acrolein in sugarcane spirits involved the formation of a derivative with 2,4-dinitrophenylhydrazine (2,4-DNPH) and subsequent analysis by HPLC.
\end{abstract}

Keywords: contaminants; congeners; Minas Gerais.

\section{Resumo}

As setenta e uma amostras de aguardentes de cana coletadas em alambiques de pequeno e médio porte, provenientes das regiões norte e sul de Minas Gerais, foram avaliadas por CLAE (Cromatografia Líquida de Alta Eficiência) quanto ao teor de acroleína. Avaliaram-se também as concentrações de etanol, acidez volátil e cobre, utilizando-se as metodologias estabelecidas pelo Ministério da Agricultura, Pecuária e Abastecimento (MAPA). Do total de amostras, 9,85\% apresentaram níveis de acroleína acima do limite legal, 21,00\% apresentaram teores de cobre e 8,85\% de acidez volátil acima dos limites estabelecidos pela legislação brasileira. Os teores de acroleína variaram de 0 a $21,97 \mathrm{mg} .100 \mathrm{~mL}^{-1}$ de etanol. Entretanto, não ocorreu diferença significativa no nível de $5 \%$ de significância entre as amostras do norte e as do sul de Minas Gerais. O método aplicado para a determinação de acroleína em aguardente de cana foi a derivação com 2,4-dinitrofenilidrazina (DNPH) e a posterior análise por CLAE. Palavras-chave: contaminantes; congêneres; Minas Gerais.

\section{Introduction}

The ability to compete is a constant concern of economic entities, and the agribusiness sector, in which the Brazilian producer is careful in order not to market lose share is not different. Among the products representing Brazilian agribusiness, sugarcane spirit is especially important since Brazil is the only country in the world that produces this beverage. There has been growing interest in increasing its export focusing on the search for new external markets.

Sugarcane spirits or cachaça is the distilled beverage obtained from the fermented broth of the sugarcane juice with alcohol concentrations of $38-54 \% \mathrm{v} / \mathrm{v}$ and $38-48 \% \mathrm{v} / \mathrm{v}$, respectively. The production of the beverage is approximately 1.5 billion liters/year. There is an annual turnover of more than $\$ 600$ million with a $27 \%$ growth expected in exports. European countries are the largest importers, while the United States participation in the market is $10.46 \%$ (SEBRAE, 2008).
Methyl alcohol (methanol), ethyl carbamate (urethane), acrolein (propenal; acrylaldehyde), sec-butyl alcohol (butan-2-ol), and butyl alcohol (butan-1-ol) are considered to be organic contaminants in sugarcane spirits, according to the Brazilian legislation (BRASIL, 2005). The incidence of these compounds in the beverage is common and may adversely affect its quality. The presence of carbonyl compounds in alcoholic beverages is related to symptoms such as nausea, vomiting, restlessness, sweating, reduced blood pressure, and headache (ANDRADE et al., 1996). For these reasons, the interest in determining the content of these compounds in foods and alcoholic or non-alcoholic beverages has increased (NASCIMENTO et al., 1997; PORRETTA; SANDEI, 1991). In addition to detrimental health effects, aldehydes and ketones affect the sensory characteristics of foods and beverages. Acrolein is highly toxic by all routes of administration. It has

\section{Received 20/1/2011}

Accepted 19/4/2012 (005237)

${ }^{1}$ Department of Food Science, Federal University of Lavras - UFLA, CP 3037, CEP 37200-000, Lavras, MG, Brazil

${ }^{2}$ Food Technology, Federal Institute of Science and Technology of Mato Grosso - IFMT, São Vicente Campus, São Vicente da Serra, CEP 78008-760, Cuiabá, MG, Brazil

${ }_{3}^{3}$ Department of Chemistry, Federal University of Lavras - UFLA, CP 3037, CEP 37200-000, Lavras, MG, Brazil, e-mail: mcardoso@dqi.ufla.br

${ }^{4}$ Department of Chemistry, Federal Institute of Science and Technology of Minas Gerais - IFMG, Belo Horizonte Campus, CEP 31270-901, Belo Horizonte, MG, Brazil

${ }^{5}$ Department of Food, Pharmacy College, Federal University of Minas Gerais - UFMG, CEP 31270-901, Belo Horizonte, MG, Brazil

${ }^{*}$ Corresponding author 
presented mutagenic characteristics and can cause irritation in the respiratory tract of animals and humans (FLEET, 2003; NOUGUER; MARTY, 1995).

According to Sauvageot et al. (2000), the formation of acrolein is associated with the metabolism of the thermofermentative bacteria Bacillus amaracrylus and Lactobacillus colinoides. The production of acrolein in cider is common and is formed from 3-hydroxypropanal, the substance responsible for the aroma of pepper in the beverage. The negative aspects are important, but it is evident that, in studies directed toward the characterization of beverages, some of these carbonyl compounds are responsible for the sensory quality of the product. Therefore, there is a clear need for better knowledge of the concentration and the influence of these compounds on food and beverages so as to achieve a positive rather than a negative effect on the final product.

The determination of the levels of acrolein, copper, volatile acidity, and alcohol in sugarcane spirits is necessary since the Brazilian legislation establishes a maximum of $5 \mathrm{mg} .100 \mathrm{~mL}^{-1}$ of anhydrous alcohol for acrolein, $5 \mathrm{mg} . \mathrm{L}^{-1}$ for copper, $150 \mathrm{mg} .100 \mathrm{~mL}^{-1}$ of anhydrous alcohol for volatile acidity, and $38 \%$ to $54 \% \mathrm{v} / \mathrm{v}$ for ethanol at $20{ }^{\circ} \mathrm{C}$. Beverages with values above these limits are considered unfit for commercialization.

The contamination of beverages by copper is principally a result of the utilization of a copper alembic. This type of still is commonly used for the production of the beverage in the state of Minas Gerais. The producers are very concerned with the contamination of the beverage by this metal since the maximum limit for this contaminant on the exterior is $2 \mathrm{mg} . \mathrm{L}^{-1}$, which makes this contaminant an obstacle for the exportation of the beverage.

Acetic acid can be formed during the catabolism of sugar in the presence of oxygen and the yeast Saccharomyces cerevisae. Large quantities of this acid are frequently associated with storage practices or contamination of the broth with acetic and other bacteria. This contamination increases the acidity and lowers the alcohol content of the beverage. The alcohol concentration can also be negatively influenced by oxidation and esterification reactions during the storage of the beverage (CARDOSO, 2006).

Considering the facts mentioned above, the present study sought to determine the acrolein, ethanol, volatile acidity and copper in different samples of sugarcane spirits produced in northern and southern Minas Gerais.

\section{Materials and methods}

Sample collection: Seventy-one samples of sugarcane liquor were collected randomly in northern and southern Minas Gerais, Brazil. These samples were obtained directly from smalland medium-sized stills; 33 were obtained from the northern region and 38 from the southern region.

Reagents: The reagents used were acrolein (Figure 1) (General Purpose Reagent-BDH Limited, England) and 2,4-dinitrophenylhydrazine (Vetec). The solvents, methanol, and acetonitrile were HPLC grade (Merck). The water used was purified by a Milli-Q system (Milipore).
Purification of 2,4-dinitrophenylhydrazine: The 2,4-dinitrophenylhydrazine was purified by heating $2.0 \mathrm{~g}$ in $50 \mathrm{~mL}$ of absolute ethanol on a water bath under constant stirring for approximately 20 minutes, followed by filtration. This procedure was repeated twice. After the third filtration, the solution was allowed to stand at room temperature until complete crystallization (about 12 hours) and filtered under vacuum.

Preparation of the standard 2,4-dinitrophenylhydrazone derivative of acrolein: The 2,4-DNPH derivative of acrolein was prepared according to the method of Shriner (SHRINER et al., 1983). A solution containing $0.4 \mathrm{~g}$ of $2,4-\mathrm{DNPH}$ (purified) in $2 \mathrm{~mL}$ of sulfuric acid was prepared; $3 \mathrm{~mL}$ of water was added dropwise with stirring until complete dissolution, and the solution was diluted with $10 \mathrm{~mL}$ of $95 \%$ ethanol. A solution containing $0.1 \mathrm{~g}$ of acrolein in $15 \mathrm{~mL}$ of ethanol was prepared in parallel. The two solutions were mixed, and the resulting mixture was allowed to stand at room temperature. The crystallization of the 2,4-dinitrophenylhydrazone occurred within ten minutes. The precipitate was filtered and purified by two recrystallizations from absolute ethanol. The purity was confirmed by determining the melting point by elemental analysis and HPLC.

For the quantitative analysis, the standard solution of the 2,4-DNPH derivative of acrolein was obtained by diluting the stock solution (1000 mg. $\mathrm{L}^{-1}$ of acetonitrile) in $45 \%$ ethanol $(\mathrm{v} / \mathrm{v})$. Six points were used to obtain the standard curve at concentrations of $0-100 \mathrm{mg} \cdot \mathrm{L}^{-1}$.

Preparation of 2,4-dinitrophenylhydrazone derivatives of the samples: A solution containing $0.4 \mathrm{~g}$ of purified 2,4-dinitrophenylhydrazine in $100 \mathrm{~mL}$ of acetonitrile was prepared. To $1.0 \mathrm{~mL}$ of this solution, were added $4.0 \mathrm{~mL}$ of the sample of sugarcane liquor and $50 \mu \mathrm{L}$ of $1.0 \mathrm{~mol} . \mathrm{L}^{-1}$ perchloric acid. The resulting solution was stirred and kept at room temperature for about 45 minutes. The samples were filtered through $0.45 \mu \mathrm{m}$ polyethylene membrane filters (Milipore), and $20 \mu \mathrm{L}$ of the solution was analyzed by HPLC (in triplicate).

Qualitative and quantitative analysis: The concentration of acrolein in the of sugarcane spirit samples was determined by high performance liquid chromatography (HPLC) based on the method of Nascimento et al. (1997) using a Shimadzu UFLC chromatograph equipped with two LC-20AD pumps, a SIL-20A auto-injector, a CTO-20AC oven, a SPD-M20A diode array detector (DAD), and a CBM-20A data recorder. A Shimadzu C18 column $(25 \times 4.6 \mathrm{~mm} \times 5 \mu \mathrm{m})$ with a flow rate of $1 \mathrm{~mL} / \mathrm{min}$ and stepwise gradient elution with $70 \%$ methanol $(\mathrm{v} / \mathrm{v})$ for 5.0 minutes, $85 \%$ methanol $(\mathrm{v} / \mathrm{v})$ for 2.0 minutes, $90 \%$ methanol $(\mathrm{v} / \mathrm{v})$ for 2.0 minutes, and $70 \%$ methanol for 3.0 minutes was used.

The quantitative conversion of aldehydes in distilled alcoholic beverages to 2,4-dinitrophenylhydrazones is provided by the use of an excess of 2,4-dinitrophenylhydrazine (LO

$$
\mathrm{H}_{2} \mathrm{C}=\mathrm{CH}-\mathrm{C}>{ }_{\mathrm{H}}=\frac{\mathrm{O}}{2}
$$

Figure 1. Structure of acrolein. 
COCO et al., 1995). The 2,4-DNPH derivative of acrolein in the samples was determined using the external standard method with detection at $365 \mathrm{~nm}$.

Analysis of volatile acidity, alcohol, and copper: The analyses of these compounds were performed in triplicate according to the methods established by the Ministério da Agricultura Pecuária e Abastecimento (BRASIL, 2005).

Statistical analysis: The results were submitted to analysis of variance and the means were compared by the Scott-Knott test at 5\% ( $\mathrm{p} \leq 0.05)$ probability (SCOTT; KNOTT, 1974; FERREIRA, 2003).

\section{Results and discussion}

The calibration curve obtained using linear regression $(y=62105.83+133404.61 x)$, plotting the peak area versus concentration, was constructed for the quantification of acrolein. The linear correlation coefficient was 0.9996 (Figure 2). The limits of detection (LD) and quantification (LQ) of the method, obtained from the parameters of the calibration curve, were $0.2066 \mathrm{mg} . \mathrm{L}^{-1}\left(0.0516 \mathrm{mg} .100 \mathrm{~mL}^{-1}\right.$ a.a) and $0.6886 \mathrm{mg} . \mathrm{L}^{-1}$ (0.1721 mg.100 $\mathrm{mL}^{-1}$ a.a), respectively.

The recovery was determined using a concentration of 8.0 mg. $\mathrm{L}^{-1}$ in three different samples. The recovery was $106.4 \%$, and the coefficient of variation was $5.4 \%$. This recovery is higher than the value (99\%) obtained by Nascimento et al. (1997). However, the method is considered accurate and reliable since the recovery ranged from 80.0 to $110.0 \%$, and this range has been considered to be acceptable in validation studies of the method (BRITO et al., 2003). The chromatogram of the 2,4-DNPH derivative of the acrolein standard and the chromatogram of the 2,4-DNPH derivative of acrolein from a sugarcane spirit sample are presented in Figure 3. The results obtained for the distilled sugarcane spirits produced in northern (NM) and southern (SM) Minas Gerais are presented in Table 1.

There was no significant difference between the samples produced in northern and southern Minas Gerais with respect to the acrolein concentration, which ranged from 0 to $25.97 \mathrm{mg} .100 \mathrm{~mL}^{-1}$ of ethanol with a mean concentration of $2.30 \mathrm{mg} .100 \mathrm{~mL}^{-1}$. Of the $33 \mathrm{NM}$ samples and $38 \mathrm{SM}$ samples, $12.12 \%$ and $7.89 \%$, respectively, presented concentrations above the limit of $5 \mathrm{mg} .100 \mathrm{~mL}^{-1}$ established by Brazilian legislation (BRASIL, 2005). Nascimento et al. (1997) found acrolein concentration values ranging from 0 to $0.660 \mathrm{mg} .100 \mathrm{~L}^{-1}$ of ethanol in 56 samples of sugarcane spirits produced in several Brazilian states. Subsequently, Nascimento et al. (1998), analyzing 35 samples of sugarcane spirits, found an average acrolein content of $0.094 \mathrm{mg} .100 \mathrm{~mL}^{-1}$ of ethanol, a value well below those found in the present study. Braga (2006) found acrolein concentrations below $0.7 \mathrm{mg} .100 \mathrm{~mL}^{-1}$ of ethanol in sugarcane spirits produced with three strains of yeast and temperature-controlled fermentation $\left(20\right.$ and $\left.32^{\circ} \mathrm{C}\right)$.

The sugarcane spirits produced in the NM region presented an average ethanol content of $43.82 \%$ by volume, ranging from $35.38 \%$ to $52.21 \%$ by volume at $20{ }^{\circ} \mathrm{C}$. The average content of the spirits produced in the SM region was $39.82 \%$, ranging from 32.62 to $48.28 \%$ of ethanol by volume at $20^{\circ} \mathrm{C}$. Of all SM and NM samples, $23.68 \%$ and $3.03 \%$, respectively, were below the minimum limit. Therefore, there is a high proportion of beverages with ethanol concentrations below the minimum legal limit, which is $38 \% \mathrm{v} / \mathrm{v}$ of ethanol at $20^{\circ} \mathrm{C}$, even though the ethanol content can be easily controlled (BRASIL, 2005).

The mean concentrations found for copper were 3.01 (NM) and $4.64 \mathrm{mg} . \mathrm{L}^{-1}(\mathrm{SM})$ with values ranging from 0.12 to $8.38 \mathrm{mg} . \mathrm{L}^{-1}$ and 0.96 to $19.40 \mathrm{mg} . \mathrm{L}^{-1}$, respectively. There was a significant difference between the sugarcane spirits from the northern and southern regions, and $21 \%$ of the samples were above the limit of $5 \mathrm{mg} . \mathrm{L}^{-1}$. These values are higher than those found by Fernandes et al. (2007), which ranged from 0.2 to $10.7 \mathrm{mg} . \mathrm{L}^{-1}$ for copper in cachaças produced in southern Minas Gerais. In that same period, Miranda et al. (2007) found values ranging from 0 to $12 \mathrm{mg} . \mathrm{L}^{-1}$ in 94 different samples of sugarcane spirits, and $15 \%$ of the samples presented concentrations above the maximum legal limit.

The copper in the distilled sugarcane spirits originates from stills made of copper, stills made partly of stainless steel and partly of copper (such as the condenser coil), or from stills in which the column is made of stainless steel with a copper coating

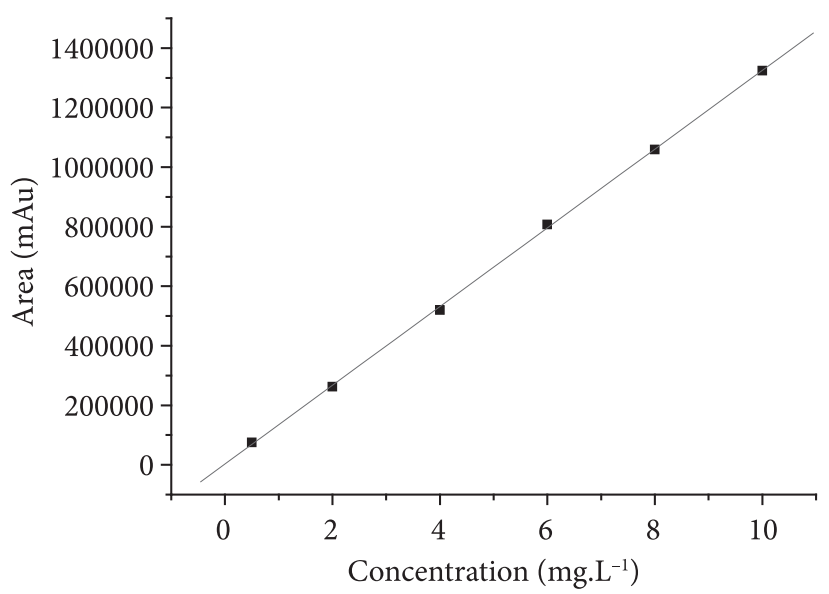

Figure 2. Calibration curve for quantification of acrolein.

Table 1. Mean concentration of acrolein, alcohol, volatile acidity, and copper in sugarcane spirits produced in the northern (NM) and southern (SM) Minas Gerais ${ }^{\mathrm{a}}$.

\begin{tabular}{ccccc}
\hline Region & $\begin{array}{c}\text { Acrolein } \\
\left(\mathrm{mg} .100 \mathrm{~mL}^{-1} \text { of ethanol }\right)\end{array}$ & $\begin{array}{c}\text { Ethanol concentration } \\
\left(\% \mathrm{v} / \mathrm{v} \text {, at } 20^{\circ} \mathrm{C}\right)\end{array}$ & $\begin{array}{c}\text { Copper } \\
\left(\mathrm{mg} . \mathrm{L}^{-1}\right)\end{array}$ & $\begin{array}{c}\text { Volatile acidity } \\
\left(\mathrm{mg}^{\mathrm{a}} 100 \mathrm{~mL}^{-1} \mathrm{de} \text { ethanol }\right)\end{array}$ \\
\hline $\mathrm{NM}$ & $2.55^{\mathrm{a}}$ & $43.82^{\mathrm{a}}$ & $3.01^{\mathrm{a}}$ & $79.12^{\mathrm{a}}$ \\
$\mathrm{SM}$ & $2.09^{\mathrm{a}}$ & $39.82^{\mathrm{b}}$ & $4.64^{\mathrm{b}}$ & $89.96^{\mathrm{a}}$ \\
\hline
\end{tabular}

a,b Means with the same letter in a column do not differ by the Scott-Knott test at a level of 0.05 . 

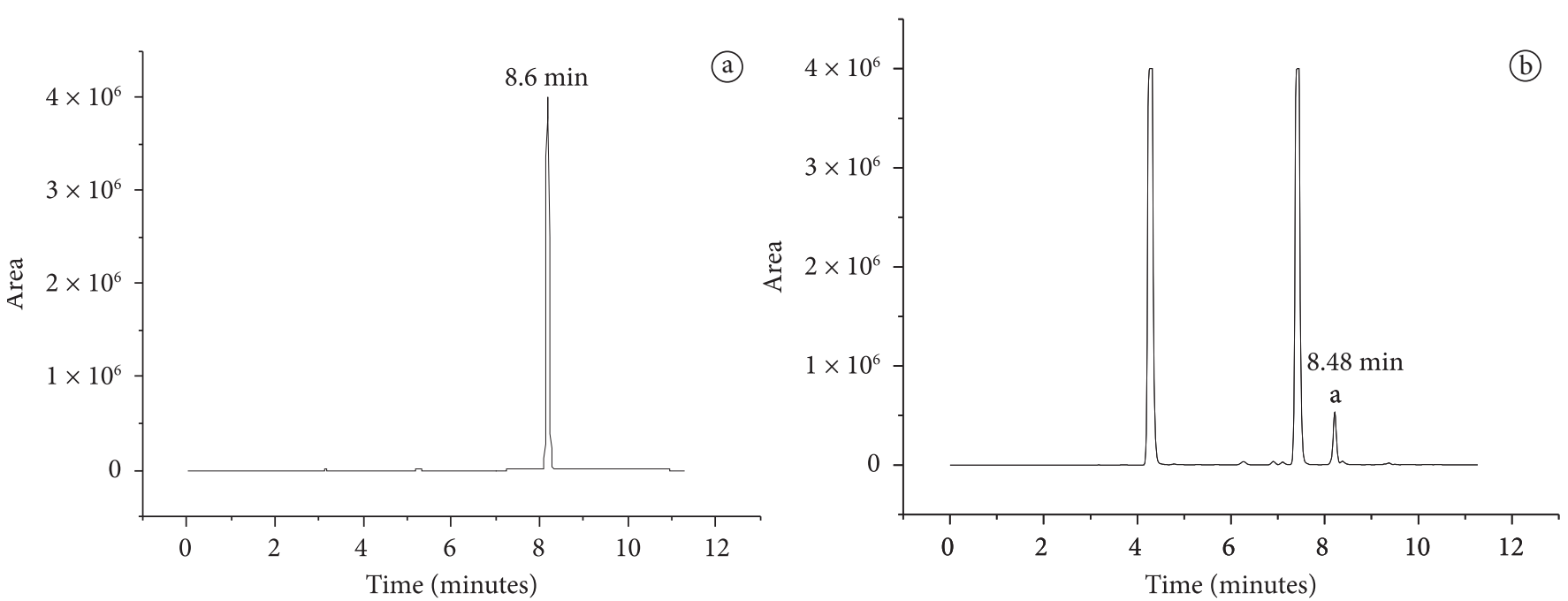

Figure 3. Chromatogram of the 2,4-DNPH derivative of the acrolein standard (a) and chromatogram of distilled sugarcane spirit samples (b) showing the peak corresponding to 2,4-DNPH derivative of acrolein ${ }^{\mathrm{a}}$.

or a screen made of copper wire (MASSON et al., 2007). This metal can be obtained from the dissolution of verdigris (basic copper carbonate) that forms inside the still and internal parts of the coil (CARDOSO, 2006). The lack of copper in the still and even in the distillation columns leads to a different effect on the organoleptic characteristics of the product and typical of a sulfide flavor (NASCIMENTO et al., 1998). Good production practices avoid the excess of this substance in the beverage.

The average volatile acidity (acetic acid) content was $79.12 \mathrm{mg} .100 \mathrm{~mL}^{-1}$ of ethanol for the NM samples and $89.96 \mathrm{mg} .100 \mathrm{~mL}^{-1}$ of ethanol for the SM samples, while $9.85 \%$ of the total number of samples presented contents above the maximum permitted level of $150 \mathrm{mg} .100 \mathrm{~mL}^{-1}$ of ethanol. The high acidity in sugarcane spirits can be attributed to contamination of the cane or the fermented mash by acetic and other types of bacteria, either during the storage of sugarcane or in the sugarcane juice, so that part of the substrate undergoes acetic fermentation, thereby increasing the acidity and reducing the efficiency of ethanol production (CARDOSO, 2006).

\section{Conclusions}

Of the 71 samples, $9.85 \%, 21.00 \%$, and $8.85 \%$ showed levels of acrolein, copper and volatile acidity, respectively, above the limits established by Brazilian legislation, while $26.71 \%$ had alcohol concentrations below the minimum threshold. The analytical method developed for the determination of acrolein in sugarcane spirits involved the formation of a dinitrophenylhydrazone derivative with subsequent analysis by high performance liquid chromatography. This method proved adequate for the determination of this substance in distilled sugarcane spirits.

\section{Acknowledgements}

The authors are grateful for the financial support and fellowship provided by the foundations Conselho Nacional de Desenvolvimento Científico e Tecnológico (CNPq), Coordenação de Aperfeiçoamento de Pessoal de Nível Superior (CAPES - PIQDTEC program), and the Fundação de Amparo e Pesquisa do Estado de Minas Gerais (FAPEMIG). The authors also acknowledge the producers for providing the samples, the Department of Chemistry and Food Science at UFLA, and the Federal Institute of Mato Grosso for the support with the chemical analyses.

\section{References}

ANDRADE, J. B. et al. Spectofluorimetric determination of formaldehyde in liquid samples. American Laboratory, v. 28, p. 56-58, 1996.

BRAGA, V. S. A influência da temperatura na condução de dois processos fermentativos para produção de cachaça. 2006. $90 \mathrm{f}$. Dissertação (Mestrado em Ciência e Tecnologia de Alimentos)Escola Superior de Agricultura Luiz de Queiroz, Universidade de São Paulo, Piracicaba, 2006.

BRASIL. Ministério da Agricultura, Pecuária e do Abastecimento. Instrução normativa $n^{\circ} 13$, de 29 de junho de 2005. Aprova o Regulamento Técnico para Fixação dos Padrões de Identidade e Qualidade para Aguardente de Cana e para Cachaça. Diário Oficial da União, Brasília, 30 jun. 2005. Seção 1, n. 124.

BRITO, N. M. et al. Validação de métodos analíticos: estratégia e discussão. Pesticidas: Revista de Ecotoxicologia e Meio Ambiente, v. 13, p. 129-146, 2003.

CARDOSO, M. G. Produção de aguardente de cana. 2. ed. Lavras: UFLA, 2006. 445 p.

FERNANDES, W. J. et al. Physicochemical quality of a blend of domestic cachaças from the south of Minas Gerais. Journal of Food Composition and Analysis, v. 20, p. 257-261, 2007. http://dx.doi. org/10.1016/j.jfca.2006.01.012

FERREIRA, D. F. Sisvar. versão 4.6, Build 61. Lavras: DEX/UFLA, 2003.

FLEET, G. H. Yeast interactions and wine flavor. Food Science Technology, v. 86, p. 11-22, 2003.

LO COCO, F. et al. Liquid chromatographic determination of 2-furaldehyde and 5-hydroxymethyl-2-furaldehyde in beer. 
Analytical Chemistry Acta, v. 306, p. 57-64, 1995. http://dx.doi. org/10.1016/0003-2670(94)00675-C

MASSON, J. et al. Parâmetros físico-químicos e cromatográficos em aguardentes de cana queimada e não queimada. Ciência e Agrotecnologia, v. 31, n. 6, p. 1805-1810, 2007. http://dx.doi. org/10.1590/S1413-70542007000600030

MIRANDA, M. B. et al. Qualidade química de cachaças e de aguardentes brasileiras. Boletim da Sociedade Brasileira de Ciência e Tecnologia dos Alimentos, v. 27, n. 4, p. 897-901, 2007.

NASCIMENTO, R. F. et al. Influência do alambique na composição química das aguardentes de cana-de-açúcar. Química Nova, v. 1, n. 6, p. 735-739, 1998. http://dx.doi.org/10.1590/S010040421998000600013

NASCIMENTO, R. F. et al. Qualitative and high-performance liquid chromatographic analysis of aldehydes in Brazilian sugar cane spirits and other distilled alcoholic beverages. Journal of Chromatography A, v. 782, p. 13-23, 1997. http://dx.doi.org/10.1016/S00219673(97)00425-1
NOUGUER, T.; MARTY, J. L. An amperometric bienzyme electrode for acetaldehyde detection. Enzyme Microbiology Technology, v. 17, p. 453-456, 1995. http://dx.doi.org/10.1016/0141-0229(94)00068-3

PORRETTA, S.; SANDEI, L. Determination of 5-(hydroxymethyl)2-f urfural (HMF) in tomato products: proposal of a rapid HPLC method and its comparison with the colorimetric method. Food Chemistry, v. 39, p. 51-57, 1991. http://dx.doi.org/10.1016/03088146(91)90084-2

SHRINER, R. L.et al. Identificação sistemática dos compostos orgânicos. 6. ed. Rio de Janeiro: Guanabara Dois, 1983. 517 p.

SAUVAGEOT, N. et al. Glycerol metabolism in Lactobacillus collinoides: production of 3-hydroxypropionaldehyde, a precursor of acrolein. International Journal Food Microbiology, v. 55, n. 1, p. 167-170, 2000. http://dx.doi.org/10.1016/S0168-1605(00)00191-4

SCOTT, A. J.; KNOTT, M. A. A cluster analysis method for grouping means in the analysis of variance. Biometrics, Raleigh, v. 30, n. 3 , p. 507-512, 1974. http://dx.doi.org/10.2307/2529204

SEBRAE. Evolução histórica do mercado de cachaça. Disponível em: <http://www.sebrae.com.br>. Acesso em: 20 out. 2008. 